\title{
THE INFLUENCE OF DIFFERENT CROP ROTATIONS AND FERTILIZATION SYSTEMS ON CHERNOZEM SOIL BULK DENSITY
}

\author{
Lucia Macrii $^{1, *}$, Dorin Cebanu ${ }^{2}$, Dionisie Zaharco ${ }^{2}$ \\ ${ }^{1}$ Alecu Russo Balti State University, 38, Puskin street, Balti, Moldova \\ ${ }^{2}$ Selectia Research Institute of Field Crops, 28, Calea Iesilor street, Balti, Moldova
}

Current Trends in

Natural Sciences

\begin{abstract}
The soil health can be deduced by chemical, biological and physical properties. This triad of features influence each other and equally determines soil quality and fertility. The paper includes the study regarding physical state of the chernozem soil characterized by bulk density - soil physical property that estimate soil compaction.

The study took place in long-term field experiments of the Selectia Research Institute of Field Crop located in the North part of Moldova. The experimental data were obtained in 2019-2020 agriculture year. The soil bulk density, studied in different crop rotations and fertilization systems, was determined under winter wheat agrocenosis after harvesting in the $0-40 \mathrm{~cm}$ soil layer.

The researches has shown that chernozem soil bulk density registered more favorable indices in crop rotations that include: perennial legumes and grasses in a mixture or only perennial legumes; less row crops - which means minimizing tillage (mechanic disturbance of soil). Regarding fertilization systems - the soil compaction is lower on the plots with adequate amount of organic fertilizer.
\end{abstract}

Keywords: bulk density, chernozem, crop rotations, fertilization systems.

\section{INTRODUCTION}

The Chernozem was the centre of attention in the beginning of soil science towards the end of the nineteenth century but during the last century, under increasingly industrial farming, it has suffered profound with known and unknown consequences. The root of the problem is the replacement of the perennial native grassland with annual crops. A new paradigm of sustainable intensification means: maximum annual return of fresh organic residues, continuous ground cover of growing crops or a mulch of crop residues, rational fertilization, zero tillage, and integration of crops and livestock within the framework of a diverse crop rotation (Boincean and Dent, 2019).

The paper includes physical state study of the chernozem soil in long field experiments, characterized by bulk density - one of the most used soil physical property that estimate edaphic volume (soil compaction) on which depends rooting depth. According to Canarache, bulk density is an integral parameter of the soil physical state quality, a relatively independent property, whose knowledge provides elements of soil physical characterization on its own (Canarache, 1990).

The research of soil bulk density was conducted in different crop rotations and fertilization systems that denote various soil management practices. Conceptual, the crop rotation is designed to diversify the crops remaining consequences on the soil and agroecosystem as a whole. 


\begin{tabular}{|c|c|}
\hline \multicolumn{2}{|c|}{$\begin{array}{l}\text { Current Trends in Natural Sciences } \\
\text { Vol. 10, Issue 20, pp. 112-117, } 2021 \\
\text { ps://doi.org/10.47068/ctns.2021.v10i20.015 }\end{array}$} \\
\hline $\begin{array}{l}\text { Current Trends in Natural Sciences (on-line) } \\
\text { ISSN: 2284-953X } \\
\text { ISSN-L: 2284-9521 }\end{array}$ & $\begin{array}{r}\text { Current Trends in Natural Sciences (CD-Rom) } \\
\text { ISSN: 2284-9521 } \\
\text { ISSN-L: 2284-9521 }\end{array}$ \\
\hline
\end{tabular}

The rotations can have positive impacts on soil physical health and more diversified rotations tend to have greater improvements and the presence of grasses with their fibrous rooting systems all contribute to improve soil health (Merfield, 2019).

\section{MATERIALS AND METHODS}

The study took place in long-term field experiments of the Selectia Research Institute of Field Crops located in the Northern part of Moldova, in naturale area Bălți Steppe known by the chernozem - black earth.

Research objects included agroecosystems with different crop rotations and fertilization systems of the following field experiments: 1 . The long-term field experiment on ecological agriculture which include three crop rotations managed within three main fertilization blocks (Table 1) (the crop rotation no. 2 differ from the $1^{\text {st }}$ crop rotation by supplementing with crop residues);

Table 1 The scheme of long-term field experiment on ecological agriculture (2019-2020 agricultural year)

\begin{tabular}{|c|c|c|c|c|c|c|c|c|c|}
\hline & \multicolumn{3}{|c|}{ The $1^{\text {st }}$ Block } & \multicolumn{3}{|c|}{ The $2^{\text {nd }}$ Block } & \multicolumn{3}{|c|}{ The $3^{\text {rd }}$ Block } \\
\hline & \multicolumn{3}{|c|}{ without fertilizers } & \multicolumn{3}{|c|}{ with organic fertilizers } & \multicolumn{3}{|c|}{$\begin{array}{l}\text { with organic }+ \text { mineral }(\mathrm{NPK}) \\
\text { fertilizers }\end{array}$} \\
\hline & \multicolumn{3}{|c|}{ Crop rotation no. } & \multicolumn{3}{|c|}{ Crop rotation no. } & \multicolumn{3}{|c|}{ Crop rotation no. } \\
\hline & 1 & 2 & 3 & 1 & 2 & 3 & 1 & 2 & 3 \\
\hline 1 & $\begin{array}{l}\text { Corn for } \\
\text { grain }\end{array}$ & $\begin{array}{l}\text { Corn for } \\
\text { grain }\end{array}$ & $\begin{array}{l}\text { Corn for } \\
\text { grain }\end{array}$ & $\begin{array}{l}\text { Corn for } \\
\text { grain }\end{array}$ & $\begin{array}{l}\text { Corn for } \\
\text { grain }\end{array}$ & $\begin{array}{l}\text { Corn for } \\
\text { grain }\end{array}$ & $\begin{array}{l}\text { Corn for } \\
\text { grain, } \\
\mathrm{N}_{70}\end{array}$ & $\begin{array}{l}\text { Corn for } \\
\text { grain, } \\
\mathrm{N}_{70}\end{array}$ & $\begin{array}{c}\text { Corn for } \\
\text { grain, } \\
\mathrm{N}_{70}\end{array}$ \\
\hline 2 & $\begin{array}{l}\text { Winter } \\
\text { barley }\end{array}$ & $\begin{array}{l}\text { Winter } \\
\text { barley }\end{array}$ & $\begin{array}{l}\text { Winter } \\
\text { barley }\end{array}$ & $\begin{array}{l}\text { Winter } \\
\text { barley }\end{array}$ & $\begin{array}{c}\text { Winter } \\
\text { barley } \\
5,7 \mathrm{t} / \mathrm{ha} \\
\text { crop } \\
\text { residues }\end{array}$ & $\begin{array}{l}\text { Winter } \\
\text { barley }\end{array}$ & $\begin{array}{c}\text { Winter } \\
\text { barley, } \\
\mathrm{N}_{60}\end{array}$ & $\begin{array}{c}\text { Winter } \\
\text { barley + } \\
\mathrm{N}_{60} 5,7 \\
\text { t/ha crop } \\
\text { residues }\end{array}$ & $\begin{array}{c}\text { Winter } \\
\text { barley } \\
\mathrm{N}_{60}\end{array}$ \\
\hline 3 & $\begin{array}{l}\text { Alfalfa + } \\
\text { Ryegrass }\end{array}$ & $\begin{array}{l}\text { Alfalfa + } \\
\text { Ryegrass }\end{array}$ & $\begin{array}{l}\text { Corn for } \\
\text { grain }\end{array}$ & $\begin{array}{c}\text { Alfalfa + } \\
\text { Ryegrass } \\
40 \text { t/ha } \\
\text { manure }\end{array}$ & $\begin{array}{c}\text { Alfalfa + } \\
\text { Ryegrass } \\
20 \text { t/ha } \\
\text { manure + } \\
3,3 \text { t/ha } \\
\text { crop } \\
\text { residues }\end{array}$ & $\begin{array}{l}\text { Corn for } \\
\text { grain } \\
40 \text { t/ha } \\
\text { manure }\end{array}$ & $\begin{array}{c}\text { Alfalfa }+ \\
\text { Ryegrass } \\
\mathrm{N}_{50} \mathrm{P}_{30} \mathrm{~K}_{3} \\
0 \\
40 \mathrm{t} / \mathrm{ha} \\
\text { manure }\end{array}$ & $\begin{array}{c}\text { Alfalfa + } \\
\text { Ryegrass } \\
\mathrm{N}_{75} \mathrm{P}_{30} \mathrm{~K}_{3} \\
0 \\
20 \mathrm{t} / \mathrm{ha} \\
\text { manure + } \\
3,3 \mathrm{t} / \mathrm{ha} \\
\text { crop } \\
\text { residues }\end{array}$ & $\begin{array}{c}\text { Corn for } \\
\text { grain } \\
\mathrm{N}_{60} \mathrm{P}_{30} \mathrm{~K}_{3} \\
0 \\
40 \mathrm{t} / \mathrm{ha} \\
\text { manure }\end{array}$ \\
\hline 4 & $\begin{array}{l}\text { Alfalfa }+ \\
\text { Ryegrass } \\
\left(2^{\text {nd }} \text { year }\right)\end{array}$ & $\begin{array}{l}\text { Alfalfa + } \\
\text { Ryegrass } \\
\left(2^{\text {nd }} \text { year }\right)\end{array}$ & $\begin{array}{c}\text { Sunflowe } \\
\text { r }\end{array}$ & $\begin{array}{l}\text { Alfalfa }+ \\
\text { Ryegrass } \\
\left(2^{\text {nd }} \text { year }\right)\end{array}$ & $\begin{array}{l}\text { Alfalfa + } \\
\text { Ryegrass } \\
\left(2^{\text {nd }} \text { year }\right)\end{array}$ & $\begin{array}{c}\text { Sunflowe } \\
\mathrm{r}\end{array}$ & $\begin{array}{l}\text { Alfalfa }+ \\
\text { Ryegrass } \\
\left(2^{\text {nd }} \text { year }\right)\end{array}$ & $\begin{array}{l}\text { Alfalfa }+ \\
\text { Ryegrass } \\
\left(2^{\text {nd }} \text { year) }\right.\end{array}$ & $\begin{array}{l}\text { Sunflowe } \\
\text { r N }_{45} \mathrm{~K}_{95}\end{array}$ \\
\hline 5 & $\begin{array}{l}\text { Alfalfa }+ \\
\text { Ryegrass } \\
\left(3^{\text {rd }} \text { year }\right)\end{array}$ & $\begin{array}{l}\text { Alfalfa }+ \\
\text { Ryegrass } \\
\left(3^{\text {rd }} \text { year }\right)\end{array}$ & $\begin{array}{c}\text { Spring } \\
\text { vetch and } \\
\text { Oat } \\
\text { mixture } \\
\text { for green } \\
\text { mass }\end{array}$ & $\begin{array}{l}\text { Alfalfa }+ \\
\text { Ryegrass } \\
\left(3^{\text {rd }} \text { year }\right)\end{array}$ & $\begin{array}{l}\text { Alfalfa + } \\
\text { Ryegrass } \\
\left(3^{\text {rd }} \text { year }\right)\end{array}$ & $\begin{array}{c}\text { Spring } \\
\text { vetch and } \\
\text { Oat } \\
\text { mixture } \\
\text { for green } \\
\text { mass } 30 \\
\text { t/ha } \\
\text { manure }\end{array}$ & $\begin{array}{l}\text { Alfalfa }+ \\
\text { Ryegrass } \\
\left(3^{\text {rd }} \text { year }\right)\end{array}$ & $\begin{array}{l}\text { Alfalfa + } \\
\text { Ryegrass } \\
\left(3^{\text {rd }} \text { year }\right)\end{array}$ & $\begin{array}{c}\text { Spring } \\
\text { vetch and } \\
\text { Oat } \\
\text { mixture } \\
\text { for green } \\
{\text { mass } \mathrm{N}_{30}}_{+30 \mathrm{t} / \mathrm{ha}} \\
\text { manure }\end{array}$ \\
\hline
\end{tabular}




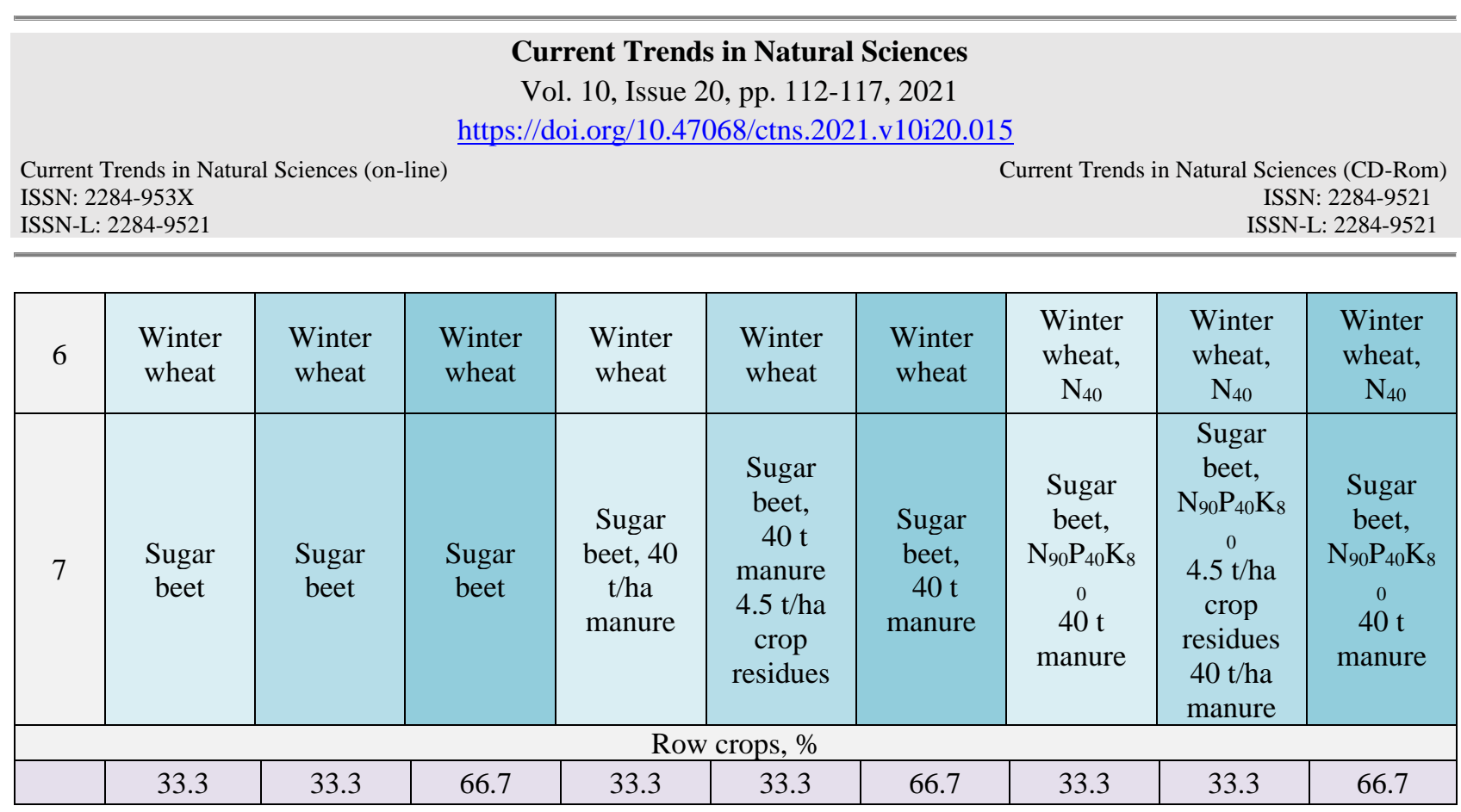

2. The long-term field experiment on crop rotations - include crop rotations differentiated by crops structure and degree of organic and mineral fertilization (Table 2).

Table 2. The scheme of long-term field experiment on crop rotations (2019-2020 agricultural year)

\begin{tabular}{|c|c|c|c|c|c|c|}
\hline $\begin{array}{c}\text { Field } \\
\text { no. }\end{array}$ & $\begin{array}{c}\text { Crop rotation } \\
\text { no. } 7\end{array}$ & $\begin{array}{l}\text { Crop rotation } \\
\text { no. } 5\end{array}$ & $\begin{array}{c}\text { Crop rotation } \\
\text { no. } 4\end{array}$ & $\begin{array}{c}\text { Crop rotation } \\
\text { no. } 2\end{array}$ & $\begin{array}{c}\text { Crop rotation } \\
\text { no. } 1\end{array}$ & Crop rotation no. 8 \\
\hline 11 & Sugar beet & $\begin{array}{l}\text { Alfalfa } \\
\left(1^{\text {st }} \text { year }\right)\end{array}$ & $\begin{array}{c}\text { Sugar beet, } \\
\mathrm{N}_{60} \mathrm{P}_{30} \mathrm{~K}_{30}+ \\
40 \text { t/ha } \\
\text { manure }\end{array}$ & $\begin{array}{l}\text { Corn for } \\
\text { grain, } \\
\mathrm{N}_{60} \mathrm{P}_{30} \mathrm{~K}_{30}\end{array}$ & $\begin{array}{c}\text { Sugar beet, } \\
\mathrm{N}_{60} \mathrm{P}_{30} \mathrm{~K}_{30}+40 \\
\text { t/ha manure }\end{array}$ & $\begin{array}{c}\text { Sunflower, } \\
\mathrm{N}_{30} \mathrm{P}_{20} \mathrm{~K}_{20} \\
+30 \text { t/ha manure }\end{array}$ \\
\hline 10 & Corn for grain & $\begin{array}{c}\text { Alfalfa } \\
\left(2^{\text {nd }} \text { year }\right)\end{array}$ & $\begin{array}{l}\text { Corn for } \\
\text { grain }\end{array}$ & Corn for grain & Corn for grain & Corn for grain \\
\hline 9 & $\begin{array}{l}\text { Spring vetch } \\
\text { and Oat } \\
\text { mixture for } \\
\text { green mass }\end{array}$ & $\begin{array}{c}\text { Alfalfa } \\
\left(3^{\text {rd }} \text { year }\right)\end{array}$ & $\begin{array}{l}\text { Winter vetch } \\
\text { and rye } \\
\text { mixture for } \\
\text { green mass, } \\
\mathrm{N}_{60} \mathrm{P}_{30} \mathrm{~K}_{30}\end{array}$ & Black folow & $\begin{array}{l}\text { Corn for } \\
\text { silage, } \\
\mathrm{N}_{60} \mathrm{P}_{30} \mathrm{~K}_{30}\end{array}$ & $\begin{array}{c}\text { Pea, } \\
\mathrm{N}_{30} \mathrm{P}_{30} \mathrm{~K}_{30}\end{array}$ \\
\hline 8 & Winter wheat & $\begin{array}{l}\text { Winter wheat, } \\
\mathrm{N}_{60} \mathrm{P}_{30} \mathrm{~K}_{30}\end{array}$ & $\begin{array}{c}\text { Winter } \\
\text { wheat, } \\
\mathrm{N}_{60} \mathrm{P}_{30} \mathrm{~K}_{30} \\
\end{array}$ & $\begin{array}{l}\text { Winter wheat, } \\
\mathrm{N}_{60} \mathrm{P}_{30} \mathrm{~K}_{30}\end{array}$ & $\begin{array}{l}\text { Winter wheat, } \\
\mathrm{N}_{60} \mathrm{P}_{30} \mathrm{~K}_{30}\end{array}$ & $\begin{array}{l}\text { Winter wheat, } \\
\mathrm{N}_{60} \mathrm{P}_{30} \mathrm{~K}_{30}\end{array}$ \\
\hline 7 & Sugar beet & $\begin{array}{c}\text { Sugar beet, } \\
\mathrm{N}_{60} \mathrm{P}_{30} \mathrm{~K}_{30}+40 \\
\text { t/ha manure }\end{array}$ & $\begin{array}{c}\text { Sugar beet, } \\
\mathrm{N}_{60} \mathrm{P}_{30} \mathrm{~K}_{30}+ \\
40 \mathrm{t} / \mathrm{ha} \\
\text { manure } \\
\end{array}$ & $\begin{array}{l}\text { Corn for } \\
\text { grain, } \\
\mathrm{N}_{60} \mathrm{P}_{30} \mathrm{~K}_{30}\end{array}$ & $\begin{array}{c}\text { Sugar beet, } \\
\mathrm{N}_{60} \mathrm{P}_{30} \mathrm{~K}_{30}+40 \\
\text { t/ha manure }\end{array}$ & $\begin{array}{c}\text { Sunflower, } \\
\mathrm{N}_{30} \mathrm{P}_{20} \mathrm{~K}_{20} \\
+30 \text { t/ha manure }\end{array}$ \\
\hline 6 & Corn for grain & Corn for grain & $\begin{array}{l}\text { Corn for } \\
\text { grain }\end{array}$ & $\begin{array}{c}\text { Pea, } \\
\mathrm{N}_{30} \mathrm{P}_{30} \mathrm{~K}_{30}\end{array}$ & Corn for grain & $\begin{array}{l}\text { Spring vetch and } \\
\text { Oat mixture for } \\
\text { green mass, } \\
\mathrm{N}_{60} \mathrm{P}_{30} \mathrm{~K}_{30}\end{array}$ \\
\hline 5 & $\begin{array}{c}\text { Winter barley } \\
\text { + Winter } \\
\text { wheat }\end{array}$ & $\begin{array}{c}\text { Winter barley } \\
\text { + Winter } \\
\text { wheat, } \\
\mathrm{N}_{60} \mathrm{P}_{30} \mathrm{~K}_{30}\end{array}$ & $\begin{array}{c}\text { Winter barley } \\
\text { + Winter } \\
\text { wheat, } \\
\mathrm{N}_{60} \mathrm{P}_{30} \mathrm{~K}_{30}\end{array}$ & $\begin{array}{c}\text { Winter barley } \\
\text { + Winter } \\
\text { wheat, } \\
\mathrm{N}_{60} \mathrm{P}_{30} \mathrm{~K}_{30}\end{array}$ & $\begin{array}{c}\text { Winter barley } \\
\text { + Winter } \\
\text { wheat, } \\
\mathrm{N}_{60} \mathrm{P}_{30} \mathrm{~K}_{30}\end{array}$ & $\begin{array}{l}\text { Winter barley }+ \\
\text { Winter wheat, } \\
\mathrm{N}_{60} \mathrm{P}_{30} \mathrm{~K}_{30}\end{array}$ \\
\hline 4 & Sunflower & $\begin{array}{l}\text { Sunflower, } \\
\mathrm{N}_{30} \mathrm{P}_{20} \mathrm{~K}_{20} \\
+30 \mathrm{t} / \mathrm{ha} \\
\text { manure }\end{array}$ & $\begin{array}{c}\text { Sugar beet, } \\
\mathrm{N}_{60} \mathrm{P}_{30} \mathrm{~K}_{30}+ \\
40 \mathrm{t} / \mathrm{ha} \\
\text { manure }\end{array}$ & $\begin{array}{l}\text { Sunflower, } \\
\mathrm{N}_{30} \mathrm{P}_{20} \mathrm{~K}_{20}\end{array}$ & $\begin{array}{l}\text { Sunflower, } \\
\mathrm{N}_{30} \mathrm{P}_{20} \mathrm{~K}_{20} \\
+30 \mathrm{t} / \mathrm{ha} \\
\text { manure }\end{array}$ & $\begin{array}{c}\text { Sugar beet, } \\
\mathrm{N}_{60} \mathrm{P}_{30} \mathrm{~K}_{30}+40 \mathrm{t} / \mathrm{ha} \\
\text { manure }\end{array}$ \\
\hline
\end{tabular}




\begin{tabular}{|c|c|c|c|c|c|c|}
\hline \multicolumn{7}{|c|}{$\begin{array}{c}\text { Current Trends in Natural Sciences } \\
\text { Vol. 10, Issue 20, pp. 112-117, } 2021 \\
\text { https://doi.org/10.47068/ctns.2021.v10i20.015 }\end{array}$} \\
\hline \multicolumn{5}{|c|}{$\begin{array}{l}\text { Current Trends in Natural Sciences (on-line) } \\
\text { ISSN: 2284-953X } \\
\text { ISSN-L: 2284-9521 }\end{array}$} & \multicolumn{2}{|c|}{$\begin{array}{r}\text { Current Trends in Natural Sciences (CD-Rom) } \\
\text { ISSN: } 2284-9521 \\
\text { ISSN-L: } 2284-9521\end{array}$} \\
\hline 3 & $\begin{array}{l}\text { Corn for } \\
\text { silage }\end{array}$ & $\begin{array}{l}\text { Corn for } \\
\text { silage, } \\
\mathrm{N}_{60} \mathrm{P}_{30} \mathrm{~K}_{30} \\
\end{array}$ & $\begin{array}{l}\text { Corn for } \\
\text { silage, } \\
\mathrm{N}_{60} \mathrm{P}_{30} \mathrm{~K}_{30} \\
\end{array}$ & $\begin{array}{l}\text { Corn for } \\
\text { silage, } \\
\mathrm{N}_{60} \mathrm{P}_{30} \mathrm{~K}_{30} \\
\end{array}$ & $\begin{array}{l}\text { Corn for } \\
\text { silage, } \\
\mathrm{N}_{60} \mathrm{P}_{30} \mathrm{~K}_{30} \\
\end{array}$ & $\begin{array}{l}\text { Corn for silage, } \\
\mathrm{N}_{60} \mathrm{P}_{30} \mathrm{~K}_{30}\end{array}$ \\
\hline 2 & Winter wheat & $\begin{array}{c}\text { Winter wheat, } \\
\mathrm{N}_{60} \mathrm{P}_{30} \mathrm{~K}_{30}\end{array}$ & $\begin{array}{l}\text { Winter } \\
\text { wheat, } \\
\mathrm{N}_{60} \mathrm{P}_{30} \mathrm{~K}_{30}\end{array}$ & $\begin{array}{l}\text { Winter wheat, } \\
\mathrm{N}_{60} \mathrm{P}_{30} \mathrm{~K}_{30}\end{array}$ & $\begin{array}{l}\text { Winter wheat, } \\
\mathrm{N}_{60} \mathrm{P}_{30} \mathrm{~K}_{30}\end{array}$ & $\begin{array}{l}\text { Winter wheat, } \\
\mathrm{N}_{60} \mathrm{P}_{30} \mathrm{~K}_{30}\end{array}$ \\
\hline \multicolumn{7}{|c|}{ Total manure, $(\mathrm{t}) /$ crop rotation } \\
\hline & - & 70 & 120 & - & 110 & 100 \\
\hline \multicolumn{7}{|c|}{ Total mineral fertilizers, $(\mathrm{kg}) /$ crop rotation } \\
\hline & - & 670 & 960 & 880 & 910 & 950 \\
\hline \multicolumn{7}{|c|}{ Row crops, $\%$} \\
\hline & 60 & 40 & 60 & 50 & 70 & 50 \\
\hline
\end{tabular}

The soil bulk density was dermined by the cylindric method (cylindric volume $=100 \mathrm{~cm}^{3}$ ), and soil moisture - by the thermostat method, both according to agroecological monitoring methods (Cerbari, 1997). The soil samples were collected from the $0-40 \mathrm{~cm}$ soil layer at each $10 \mathrm{~cm}$, under winter wheat agrocenoses after harvesting (for crop rotations long-term field experiment (Table 2) soil samples were collected from the field no. 8).

\section{RESULTS AND DISCUSSIONS}

In long-field experiment on ecological agriculture was studied 3 crop rotations designed within 3 differentiated blocks depending on fertilization system (Table 1). The crop rotations no. 1 and 2 are highlighted by the presence of perennial legumes and grasses (Alfalfa + Ryegrass for green mass - 3 years use) and small percentage (only about 33\%) of row crops. The opposite position is about the third crop rotation (no. 3), whose crops structure is devoid of perennial legumes and grasses and the row crops account about $67 \%$.

The soil bulk density data obtained under winter wheat agrocenoses of ecological agriculture longfield experiment are presented in the Table 3. The research show that soil is more compacted in the $10-40 \mathrm{~cm}$ layer under the crop rotation no. 3, where bulk density values falls between 1.38-1.45 $\mathrm{g} / \mathrm{cm}^{3}$ for all fertilization systems. The biggest soil bulk density indexes were obtained in the $1^{\text {st }}$ Block without fertilizers (soil bulk density $-1.40-1.45 \mathrm{~g} / \mathrm{cm}^{3}$ ) but not statistically significant.

The crop rotations no. 1 and 2 characterized by perennial legumes and grasses use (Alfalfa + Ryegrass for green mass - 3 years use) and less use of row crops, recorded the smallest values of soil bulk density in 0-30 cm layer (1.13-1.34 g/ $\left.\mathrm{cm}^{3}\right)$. Compared with the data of crop rotations no. 3 , lower values of soil bulk density (statistically assured) are attested for 10-30 cm layer. The soil decompactation is due to vigorous pivoting root system of Alfalfa in combination with Ryegrass fibrous root system that contributed both mechanically and chemically (through root remains) to the soil refining.

Soil supplementation with organic (The $2^{\text {nd }}$ Block) and organic + mineral fertilizers (The $3^{\text {rd }}$ Block) contributed to the decrease of soil bulk density values in all three studied crop rotations, but don't denote a statistically significant difference. The data analyze denote that the greater impact on soil bulk density decrease was due to perennial legumes and grasses both with a small percentage of row crops. 


\begin{tabular}{lcc}
\hline & $\begin{array}{c}\text { Current Trends in Natural Sciences } \\
\end{array}$ & Vol. 10, Issue 20, pp. 112-117, 2021 \\
& https://doi.org/10.47068/ctns.2021.v10i20.015 & Current Trends in Natural Sciences (CD-Rom) \\
\cline { 2 - 3 } Current Trends in Natural Sciences (on-line) & ISSN: 2284-9521 \\
ISSN: 2284-953X & & ISSN-L: 2284-9521 \\
ISSN-L: 2284-9521 & & \\
\hline
\end{tabular}

Table 3. The soil bulk density under winter wheat agrocenoses depending on crop rotation and fertilization in ecological agriculture long-term field experiment

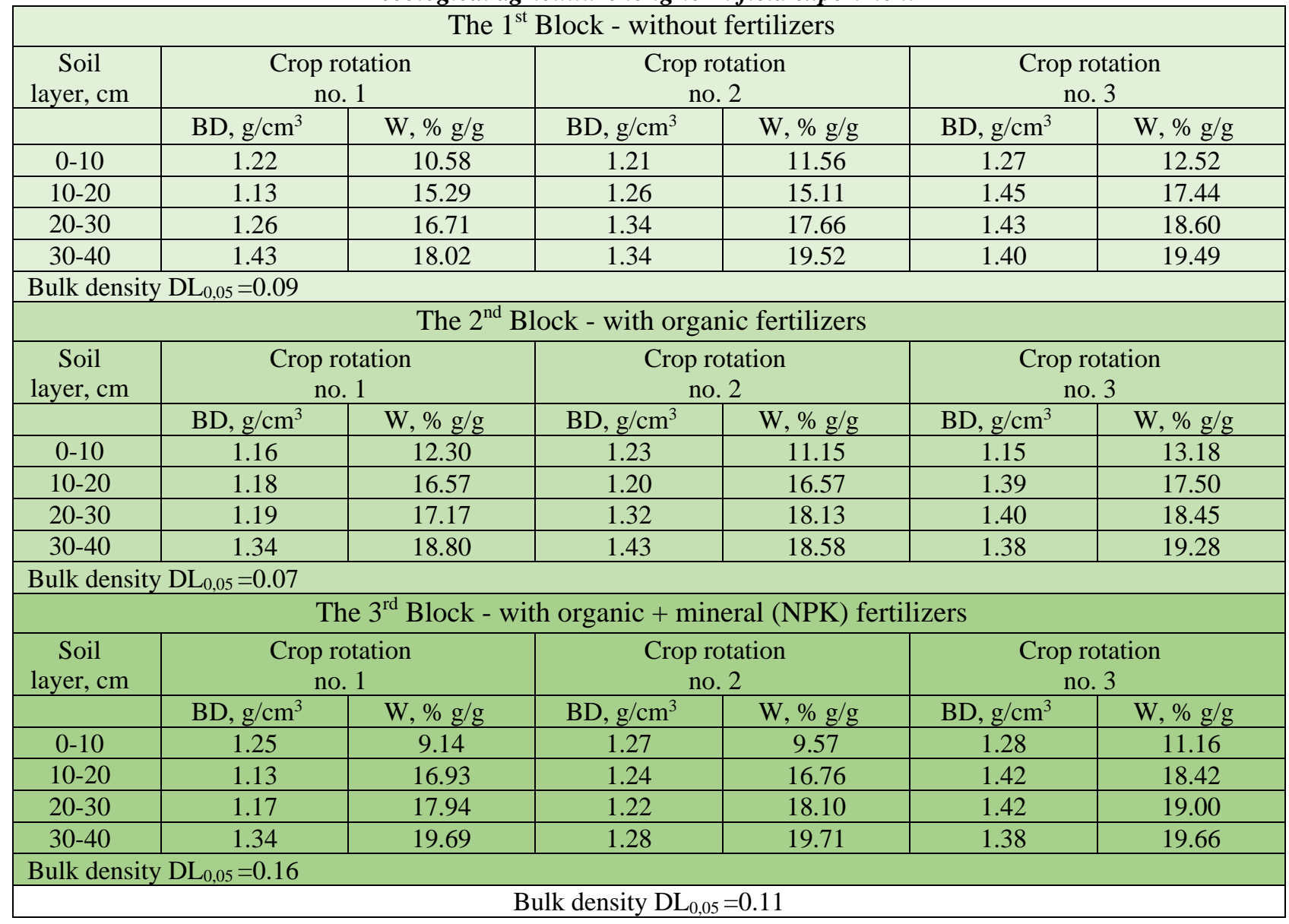

$B D-$ bulk density

W-Moisture

The long-term field experiment on crop rotations (Table 2) it's a good opportunity to study the state of soil settlment in crop rotations that differ largely by the percentage of row crops, amount of organic and mineral fertilizers, also by the presence of perennial legumes and grasses - an important key for sustainable agroecosystems.

There were studied six crop rotations. The data show (Table 4), that under winter wheat agrocenoses, after harvesting, the soil compaction is more obvious for the $10-40 \mathrm{~cm}$ soil layer, when the bulk density indexes fall within the range of $1.40-1.52 \mathrm{~g} / \mathrm{cm}^{3}$ for crop rotations no. 7, 4, 2, 1 and 8. It is also important to mention, that the highest soil bulk density value $\left(1.52 \mathrm{~g} / \mathrm{cm}^{3}\right)$ was registered for the crop rotation no. 2 which stands out with black folow, practiced before winter wheat, $50 \%$ of row crops and without organic fertilizer. The research also show that destructive effect on the soil of a high percentage of row crops/rotation $-70 \%$ (crop rotation no. 1) cannot be compensated with the organic fertilizer with the amount of $110(\mathrm{t}) / \mathrm{crop}$ rotation. Mechanic disturbance of the soil has a prevailing negative impact on it's physics.

The first layer of soil $(0-10 \mathrm{~cm})$ due to the presence of the fibrous root system of wheat, registered optimal soil bulk density values $\left(1.09-1.21 \mathrm{~g} / \mathrm{cm}^{3}\right)$ in all researched crop rotations. 


\section{Current Trends in Natural Sciences}

Vol. 10, Issue 20, pp. 112-117, 2021

https://doi.org/10.47068/ctns.2021.v10i20.015

Current Trends in Natural Sciences (on-line)

ISSN: 2284-953X

Current Trends in Natural Sciences (CD-Rom)

ISSN: 2284-9521

ISSN-L: 2284-9521

ISSN-L: 2284-9521

In the crop rotation no. 5 are found the lowest values of bulk density $\left(1.22-1.25 \mathrm{~g} / \mathrm{cm}^{3}\right)$ for $10-20$ $\mathrm{cm}$ soil layer, comparative with the other studied crop rotations. First of all, this is due to previous use of alfalfa 3 years (for green mass), completed with the use of organic (70(t)/crop rotation) and mineral fertilizers $(670(\mathrm{~kg}) /$ crop rotation), and the smallest percentage of row crops $(40 \%)$.

Table 4. The soil bulk density under winter wheat agrocenoses depending on crop rotation and fertilization in crop rotations long-term field experiment

\begin{tabular}{|c|c|c|c|c|c|c|c|c|c|c|c|c|}
\hline \multirow{3}{*}{$\begin{array}{c}\text { Soil } \\
\text { layer, } \\
\mathrm{cm}\end{array}$} & \multicolumn{12}{|c|}{ Crop rotation number } \\
\hline & \multicolumn{2}{|c|}{7} & \multicolumn{2}{|c|}{5} & \multicolumn{2}{|c|}{4} & \multicolumn{2}{|c|}{2} & \multicolumn{2}{|c|}{1} & \multicolumn{2}{|c|}{8} \\
\hline & $\begin{array}{l}\mathrm{BD}, \\
\mathrm{g} / \mathrm{cm}^{3}\end{array}$ & $\mathrm{~W}, \%$ & $\begin{array}{l}\mathrm{BD}, \\
\mathrm{g} / \mathrm{cm}^{3}\end{array}$ & $\mathrm{~W}, \%$ & $\begin{array}{l}\mathrm{BD}, \\
\mathrm{g} / \mathrm{cm}^{3}\end{array}$ & $\mathrm{~W}, \%$ & $\begin{array}{l}\mathrm{BD}, \\
\mathrm{g} / \mathrm{cm}^{3}\end{array}$ & $\mathrm{~W}, \%$ & $\begin{array}{l}\mathrm{BD}, \\
\mathrm{g} / \mathrm{cm}^{3}\end{array}$ & $\mathrm{~W}, \%$ & $\begin{array}{l}\text { BD, } \\
\mathrm{g} / \mathrm{cm}^{3}\end{array}$ & $\mathrm{~W}, \%$ \\
\hline $0-10$ & 1.21 & 20.48 & 1.09 & 21.08 & 1.09 & 21.89 & 1.18 & 20.09 & 1.20 & 19.01 & 1.12 & 20.22 \\
\hline $10-20$ & 1.49 & 17.62 & 1.22 & 14.65 & 1.40 & 16.90 & 1.52 & 17.65 & 1.44 & 17.14 & 1.42 & 16.95 \\
\hline $20-30$ & 1.45 & 16.85 & 1.25 & 14.65 & 1.40 & 16.51 & 1.45 & 16.55 & 1.47 & 16.13 & 1.49 & 16.45 \\
\hline $30-40$ & 1.42 & 17.98 & 1.49 & 16.23 & 1.41 & 16.79 & 1.44 & 17.56 & 1.47 & 16.32 & 1.44 & 17.11 \\
\hline
\end{tabular}

$B D-$ bulk density

W-Moisture

\section{CONCLUSIONS}

The physical state study of the chernozem soil in long field experiments, characterized by bulk density, denote that for the adequate soil physical condition it is necessary to design crop rotations with great diversity of crops including perennial legumes and grasses that contribute both mechanically and chemically (through root remains) to the soil refining.

The soil supplementation with organic and organic accompanied by mineral fertilizers contribute to the decrease of soil bulk density values, but at a high degree of soil disturbance, due to high percentage of row crops and black folow, the organic fertilizer cannot recover significant the physical soil degradation.

In order to keep the soil in good physical state, the agroecosystem management practices aimed at improving soil health (diversified crop rotations, perennial legumes and grasses, less mechanic disturbance of soil, adequate amount of organic fertilizer accompanied by mineral ones) must be applied synergistically.

\section{ACKNOWLEDGEMENTS}

The results were obtained within the state program (2020-2023) - Agroecological management of agroecosystems with field crops adapted to challenges of modern agriculture in the Republic of Moldova.

\section{REFERENCES}

Boincean, B., Dent, D. (2019). Farming the Black Earth (Sustainable and Climate-Smart Management of Chernozem Soils). Springer International Publishing, Switzerland, 8-10.

Canarache A. (1990). Fizica solurilor agricole [The agricultural soil physics]. Ceres publishing, Bucuresti, 50-52.

Cerbari, V. (1997). Metodica instituirii monitoringului funciar în Republica Moldova [The methodology of establishing land monitoring in the Republic of Moldova]. Chisinau, 117-124.

Merfield, C. N. (2019). Rotations and their impact on soil health. Report number 03-2019. The BHU Future Farming Centre, Lincoln, New Zealand, 9-10, from http://www.bhu.org.nz/future-farming-centre/ffc/information/cropmanagement/production/rotations-and-their-impact-on-soil-health-2019-ffc-merfield.pdf 